\title{
Intracranial Sewing Needles in an Adult Patient
}

\author{
Erişkin Bir Hastada Intrakranial Dikiş İğneleri
}

\author{
Atilla KAZANCI ${ }^{1}$, Halil Ibrahim OZDEMIR ${ }^{2}$, Burak KAZANCI ${ }^{3}$, Dilek OZTURK KAZANCI ${ }^{4}$, Uygur ER $^{3}$ \\ ${ }^{1}$ TOBB University of Economics and Technology Hospital, Department of Neurosurgery, Ankara, Turkey \\ ${ }^{2}$ Ministry of Health Corum State Hospital, Department of Neurosurgery, Corum, Turkey \\ ${ }^{3}$ Ministry of Health Yildirim Beyazit Education and Research Hospital, Department of Neurosurgery, Ankara, Turkey \\ ${ }^{4}$ Ministry of Health Yuksek İhtisas Education and Research Hospital, Department of Anesthesiology, Ankara, Turkey \\ Presented in: Annual Meeting of Turkish Neurosurgical Society Abstract Book 2004 (292).
}

Correspondence address: Atilla KAZANCI / E-mail: atillakazanci@gmail.com

\begin{abstract}
A 37-year-old patient is reported with intracranial sewing needles, which were located in the right frontal lobe. Both clinical and radiological findings suggested that these needles must have been introduced in infancy before the closure of anterior fontanelle during an unsuccessful homicide. Usually intracranial foreign objects are placed due to penetrating trauma or surgical procedures. Child abuse has been known for centuries. Many types of physical traumas have been reported, especially in Western countries. In Iran, insertion of sewing needles into the brain aiming to kill the infant have been seen in a lot of cases. This situation takes part in a lot of Persian stories. We reported a $37-y e a r-o l d ~ m a n$ who had 2 intracranial sewing needles with unknown etiology.
\end{abstract}

KEYWORDS: Intracranial sewing needles, Infanticide, Anterior fontanelle

öz

Sağ frontal lobunda dikiş iğneleri tespit edilen 37 yaşında bir hasta rapor edilmiştir. Hem klinik hem de radyolojik bulgular bu iğnelerin henüz anterior fontanel kapanmadan önce yenidoğan döneminde başarısız bir cinayet girişimi için yerleştirildiğini düşündürmektedir. Genelde intrakranial yabancı cisimler penetran travmalar ya da cerrahi girişimler sonucu oluşurlar. Çocukların kötüye kullanımları yüzyıllardır bilinir. Özellikle batı toplumlarında birçok çeşit fiziksel travma bildirilmiştir. İran'da bir yenidoğanı öldürmek amaçıı beyine dikiş iğnesi sokulması birçok vakada görülmüştür. Bu durum birçok Pers hikayesinde yer almaktadır. Biz etiyolojik nedeni bilinmeyen iki intrakranial dikiş iğnesi bulunan 37 yaşında bir erkek hastayı bildiriyoruz.

ANAHTAR SÖZCÜKLER: İntrakranial dikiş iğneleri, İnfantisid, Ön fontanel

\section{INTRODUCTION}

Intracranial foreign bodies are rare situations and usually secondary to traumatic brain injuries and surgical procedures. Sewing needles are perhaps the most unusual foreign bodies that may be found in the brain and may be a homicidal attempt in infancy or early childhood before the closure of fontanelles (8). We reported a 37-year-old man who had 2 intracranial sewing needles with unknown etiology.

\section{CASE REPORT}

A 37-year-old male patient admitted our hospital emergency service because of head trauma after an accident. The patient's physical and neurological examination was completely normal. Craniographies were obtained and two sewing needles directed downwards were detected (Figure 1). On the cranial CT evaluation two sewing needles near the midline were observed (Figure 2). One of the needles extended nearby the anterior horn of the lateral ventricle. Neither the patient nor his family had an idea about the insertion of the needles. Both localizations and positions of needles suggested that sewing needles were inserted through the anterior fontanelle during infancy for infanticide. No surgical procedure was applied for this patient because he had no clinical symptoms.

\section{DISCUSSION}

Usually intracranial foreign bodies come into existence by the way of cranium, orbita or ear penetrating traumas. With metallic objects other objects like shrapnel, wood pieces or bone pieces are detected as foreign bodies $(2,3,4,6,7,8)$. Surgical clips and forgotten cotton may cause granulomas in the surgical field (1). After surgical and medical procedures it was reported emboli arising from catheters, sutures and atheroma plaques may reach the brain (1). Amniotic fluid, trophoblast, air and fat emboli have also been reported (3).

In our case clinical and radiological findings suggested that the two sewing needles were inserted intentionally into the brain through the anterior fontanelle in the infancy period. Fortunately these needles did not damage any branches of the anterior cerebral artery and did not cause any infection. Notermes et al reported a similar case of homicide attempt 
during infancy (5). It is much lower probability that these needles were inserted by an older child during a game.

Usually intracranial sewing needles are detected accidentally after a minor head trauma $(1,3,5,6)$. If needles are noticed after a short time period they must be taken out because of

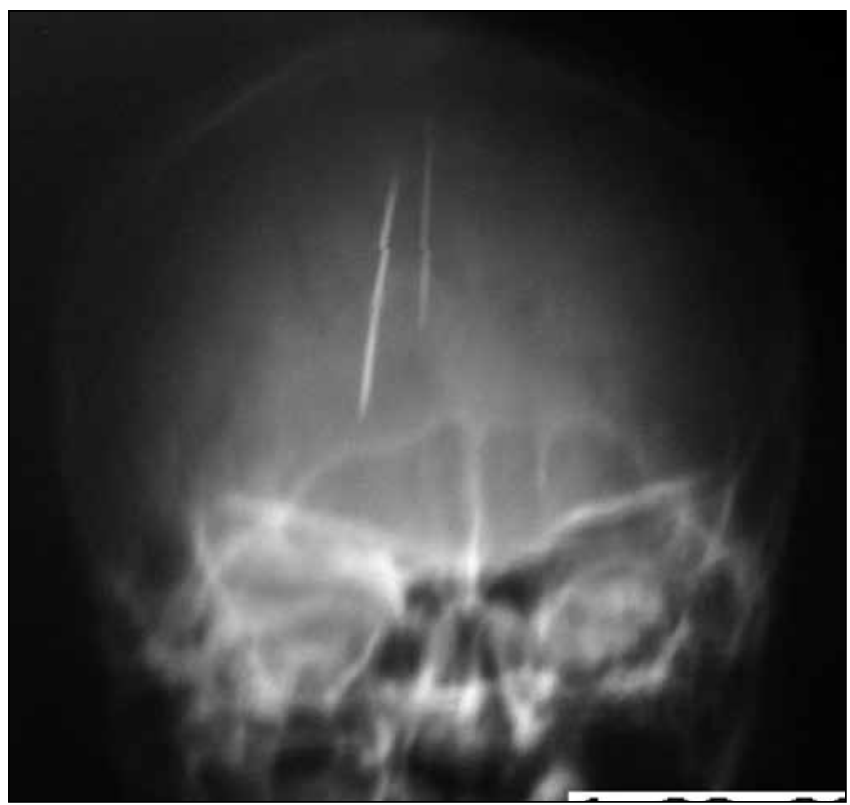

Figure 1: Craniography showing two sewing needles that are directed downwards. the infection risk. No surgical procedures are recommended in the adolescence period if there is no neurological deficit or epileptic attacks $(1,3,5,6)$.

\section{REFERENCES}

1. Abbasion K, Ameli NO, Morshed AA: Intracranial sewing needle. J Neurol Neurosurg Psychiatry 42:1046-1049,1979

2. Jinkins JR, Dadsetan MR, Sener RN, Desai S, Williams RG: Value of acute-phase angiography in the detection of vascular injuries caused by gunshot wounds to the head. Analysis of 12 cases. AJR 15:365-368,1992

3. Kuroiwa T, Tanabelt H, Ohta T: Chopstick penetration of the posterior cranial fossa, case report. Surg Neurol 43:68-69,1995

4. Nakayama T, Shimazaki K, Ono J, Ohsato K, Yamaura A: Intracranial foreign body granuloma caused by fine cotton fibers a case report. No Shinkei Geka 22:1081-1084,1994

5. Notermans NC, Ramos LM: Cranial nevre palsy as a delay complication of attempted infanticide by insertion of a stylet through the fontanelle. J Neurosurg 72:818-820,1995

6. Rahmizadeh A, Hadadien K: Intracranial swing needles. Neurosurgery 20(4): 666, 1987

7. Sener RN: Intracranial swing needles in a 20 year old patient. J Neuroradiol 24:212-214, 1997

8. Sturiale $C L$, Massimi L, Mangiola A, Pompucci A, Roselli R, Anile C: Sewing needles in the brain: Infanticide attempts or accidental insertion? Neurosurgery 67(4):1170-1179, 2010

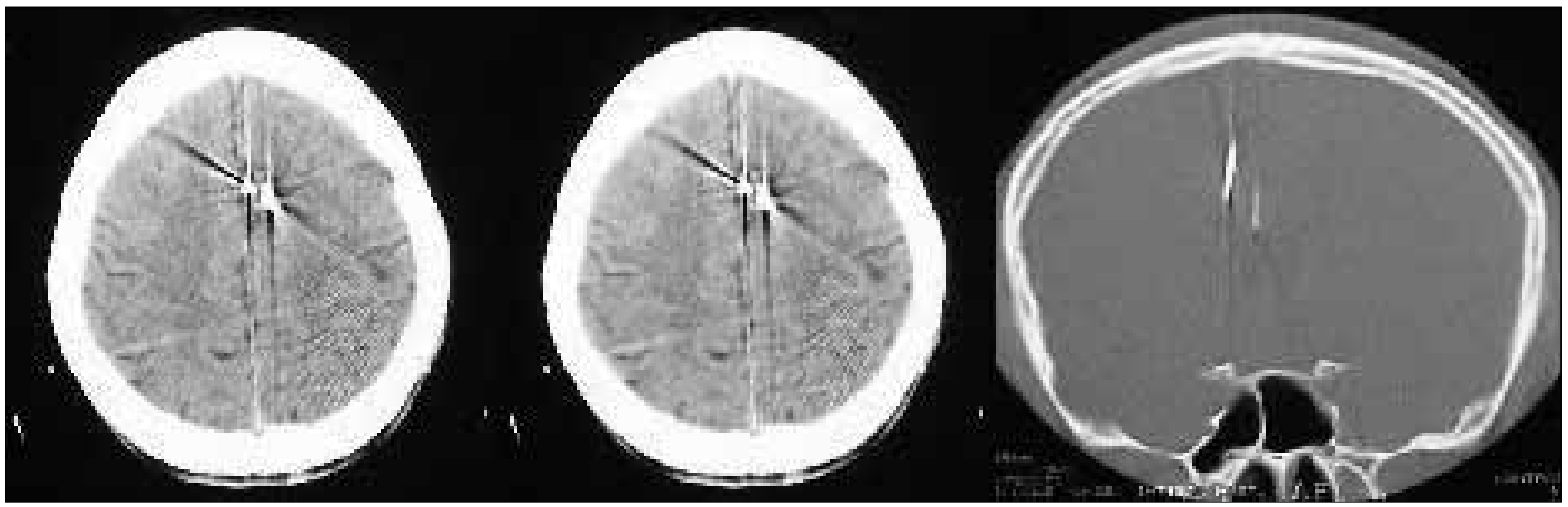

Figure 2: CT scans showing two sewing needles near midline. 